\title{
The anticancer activity of alpha-tomatine against mammary adenocarcinoma in mice
}

\author{
Pavel Tomsika, Stanislav Micuda ${ }^{b}$, Lenka Sucha ${ }^{a}$, Eva Cermakovac, Petr Suba ${ }^{a}$, Pavel Zivny ${ }^{f}$, Yvona Mazurovaa ${ }^{e}$ Jiri Knizek ${ }^{d}$, \\ Mohamed Niang ${ }^{a}$, Martina Rezacova ${ }^{a}$
}

\begin{abstract}
Aim. To evaluate the anticancer effect of alpha-tomatine (i.p.) either alone or in combination with doxorubicin (i.v.) in a mouse tumour model.

Methods. We studied the effect of repeated alpha-tomatine $(0.1-9 \mathrm{mg} / \mathrm{kg})$ and/or doxorubicin $(2 \mathrm{mg} / \mathrm{kg})$ on the growth and mitotic activity of the solid Ehrlich tumour in vivo, as well as on the survival of the tumour-bearing mice. Results. Monotherapy with alpha-tomatine had a significant dose-dependent anticancer effect which peaked at $1 \mathrm{mg} / \mathrm{kg}$. This was shown by both slowed tumour growth and reduced tumour cell proliferation. We also provide the first evidence that the combination alpha-tomatine $(1 \mathrm{mg} / \mathrm{kg})$ and doxorubicin $(2 \mathrm{mg} / \mathrm{kg})$ had a synergistic effect and significantly prolonged the survival of the mice. Neither alpha-tomatine nor doxorubicin influenced the infiltration of tumours with CD3+ lymphocytes; nor were we able to find an in vivo modulation of the key molecules of two regulatory pathways reported in vitro as the principal anti-cancer mechanisms of alpha-tomatine, i.e. iNOS and phosphorylated ERK2. However, alpha-tomatine still led to intracellular DNA inhibition and protein synthesis in Ehrlich tumour cells in a short-term culture ex vivo with $\mathrm{IC}_{50}$ values of 8.7 and $6.6 \mu \mathrm{M}$.

Conclusions. The results suggest that TOM, especially in combination with doxorubicin, may be a promising agent for the treatment of malignant solid tumours. Despite growing knowledge of the mechanisms of TOM action in cancer cells, most aspects remain unclear. Parallel organ toxicity, especially potential liver effects, requires careful attention when performing in vivo studies in the future.
\end{abstract}

Key words: alpha-tomatine, doxorubicin, cancer, survival, Ehrlich tumour

Received: January 23, 2013; Accepted with revision: April 17, 2013, Available online: May 3, 2013 http://dx.doi.org/10.5507/bp.2013.031

aDepartment of Medical Biochemistry, Charles University in Prague, Faculty of Medicine in Hradec Kralove, Hradec Kralove, Czech Republic
'Department of Pharmacology, Charles University in Prague, Faculty of Medicine in Hradec Kralove, Hradec Kralove
'Computer Technology Centre, Charles University in Prague, Faculty of Medicine in Hradec Kralove, Hradec Kralove
'Department of Medical Biophysics, Charles University in Prague, Faculty of Medicine in Hradec Kralove, Hradec Kralove
eDepartment of Histology and Embryology, Charles University in Prague, Faculty of Medicine in Hradec Kralove, Hradec Kralove
IInstitute for Clinical Biochemistry and Diagnostics, University Hospital in Hradec Kralove, Hradec Kralove
Corresponding Author: Pavel Tomsik, e-mail: tomsikp@lfhk.cuni.cz

\section{INTRODUCTION}

$\alpha$-Tomatine (TOM) is the major glycoalkaloid of tomato (Solanum lycopersicum L., syn.: Lycopersicon esculentum Mill.). The molecule is composed of an aglycone core, tomatidine, $(22 S, 25 S)$-5 $\alpha$-spirosolan-3 $\beta$-ol, which is attached with its 3-OH group to the saccharide moiety called lycotetraose (Fig. 1). In plants, TOM may provide defence against pathogenic fungi, bacteria, viruses and herbivores ${ }^{1}$. This effect corresponds with the content of the agent and changes throughout the lifespan of the tomato plant; e.g. during tomato fruit maturation, the levels of TOM decrease considerably, which, among other factors, brings about a reduction in the bitter flavour ${ }^{2}$.

In mammals, a wide variety of health-promoting properties of TOM have been reported, including the lowering of plasma concentrations of LDL and triacylglycerols ${ }^{3}$ and cardiotonic ${ }^{1}$ and antiviral activity ${ }^{4}$. TOM may also contribute to the stimulation of antigen-specific humoral and cellular immune response, including the augmenta- tion of anticancer defence ${ }^{5}$. Friedman et al. ${ }^{6}$ reported the chemopreventive effect of TOM against liver and stomach cancer in rainbow trout (Oncorhynchus mykiss Walb.). Lee et al. ${ }^{7}$ showed the antiproliferative effect of TOM (c $\sim 1 \mu \mathrm{g} / \mathrm{L}$ ) against human colon and liver cell lines, which was more powerful than that of some classical anticancer agents such as doxorubicin and camptothecin.

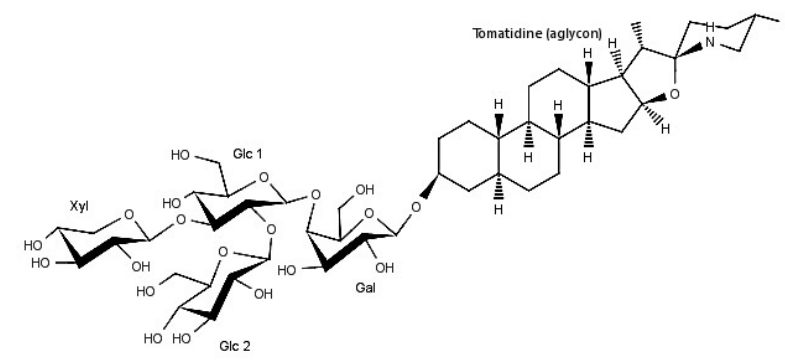

Fig. 1. Alpha-Tomatine. 
Similar results were obtained with high-tomatine extracts from green tomatoes ${ }^{8}$.

On investigating the mechanism of action, it was found that TOM affects important signaling pathways responsible for the regulation of cell proliferation, differentiation, and migration ${ }^{9,10}$. Shih et al. ${ }^{10}$ found TOM $(\mathrm{c} \leq 2 \mu \mathrm{mol} / \mathrm{L})$ to suppress invasion and migration in a human lung adenocarcinoma cell line. It also inhibited the phosphorylation of Akt (protein kinase B), a serine-threonine kinase which regulates the function of many cellular proteins involved in metastasis and the proliferation of cancer cells ${ }^{11}$, and the phosphorylation of extracellular signal-regulated kinase 1 and 2 (ERK 1,2). The ERK (extracellular regulated kinase) pathway often plays a role in oncogenic transformation and in the regulation of metalloproteinases and urokinase expression, i.e. of the enzymes which degrade the extracellular matrix and help cancer cells invade tissues and metastasize ${ }^{12,13}$. Shih et al. ${ }^{10}$ detected lower activities of metalloproteinases and urokinase in cells incubated with TOM. TOM also inhibited the activation of focal adhesion kinase, the phosphatidylinositol 3-kinase (PI3K)/Akt signal pathway, and NF-kB (nuclear factor kappa B) in cancer cells ${ }^{14,15}$. In leukemic cells, TOM induced apoptosis, which was caspase-independent and associated with the down-regulation of survivin expression and the translocation of AIF (apoptosis inducing factor) into the nucleus ${ }^{16}$. In our recent study on MOLT-4 cells, too, TOM induced caspase-independent cell death associated with an increase in $\mathrm{p} 53$ and in the mitochondrial protein PUMA. The inhibition of proliferation by alphatomatine was linked with an increase in $\mathrm{p} 21^{\mathrm{WAF} 1 / \mathrm{CIP} 1}$ level and activation of the checkpoint kinase 2 ( Chk2) ( ref. $\left.^{17}\right)$.

Despite the very encouraging data from in vitro experiments, to our knowledge only one other very recently published study has investigated the anticancer effect of TOM in a mammal model in vivo. It found that TOM at a dose of $5 \mathrm{mg} / \mathrm{kg}$ (administered i.p. every other day) inhibits the growth of HL-60 leukaemia xenografts in immunodeficient mice ${ }^{16}$. However, the effect of the therapy on mice survival or its dose dependence was not followed. In the present study, we evaluated in detail the effect of the repeated intraperitoneal administration of TOM at doses from 0.1 to $9 \mathrm{mg} / \mathrm{kg}$, either alone or in combination with doxorubicin, on tumour growth, mitotic activity, and the survival of immunocompetent mice bearing the solid Ehrlich tumour. We also tested the effect of TOM on the DNA and protein synthesis of Ehrlich tumour cells in short-term culture ex vivo. As a surrogate for potential toxicity, serum bilirubin and liver enzymes were measured.

\section{MATERIALS AND METHODS}

Design of the in vivo study. Two hundred and eight NMRI female mice weighing on average $27.2 \pm 1.50 \mathrm{~g}$ obtained from BioTest s.r.o. (Konárovice, Czech Republic - CR) were fed a standard diet and water ad libitum. The solid Ehrlich tumour was purchased from the Research Institute for Pharmacy and Biochemistry (VUFB), Prague,
$\mathrm{CR}$, and then maintained in NMRI mice by periodical transplantations in the laboratory. The homogenized tumour tissue was inoculated subcutaneously into all but 16 mice (controls without tumour) on day 0 , using $0.2 \mathrm{~mL}$ of $1 / 1(\mathrm{v} / \mathrm{v})$ homogenate freshly prepared in isotonic glucose solution. The tumour-bearing mice were then divided into 12 groups as follows: saline treated controls with the tumour; five groups of tumour-bearing animals treated with $0.1,0.3,1,3$, or $9 \mathrm{~g} \mathrm{TOM} / \mathrm{kg}$; a further five groups of tumour-bearing mice receiving $0.1,0.3,1,3$, or $9 \mathrm{~g}$ $\mathrm{TOM} / \mathrm{kg}$, but in combination with $2 \mathrm{mg} / \mathrm{kg}$ of doxorubicin (DOX). Each group consisted of 16 animals. TOM (as hydrate) was purchased from Sigma-Aldrich Co. (CR); DOX was of pharmaceutical grade (Doxorubicin Teva 0.2\%, 50 mg/25 mL, Pharmachemie B.V., Haarlem, Netherlands). The doses of TOM were selected according to reported $\mathrm{LD}_{50}$ for i.p. administration ${ }^{18}$. The i.v. dose for DOX was chosen as a suboptimal dose (our data not shown ${ }^{19}$ ) representing approximately $40 \%$ of the LD10 (ref. ${ }^{20}$ ). Both TOM (i.p.) and DOX (i.v.) were administered on days 1,4 and 7 , in volumes of $0.2 \mathrm{~mL}$ per $20 \mathrm{~g}$ body weight (DOX as solutions in $0.9 \%$ saline; TOM in $0.9 \%$ saline acidified with $\mathrm{HCl}$ ). In the groups treated with both substances, TOM was administered $30 \mathrm{~min}$ after DOX. The reason for this was the suspected vasoconstriction activity of TOM observed in our preliminary experiments (data not shown). Mice were weighed on the first, fourth, sixth and seventh days. On the eighth day, half of the mice were sacrificed; the remaining animals were left in order to observe their survival. One hour before the sacrifice of the first half of the animals, a solution of 5-bromo-2'deoxy-uridine (BrdU; $100 \mathrm{mg} / \mathrm{kg}$, Sigma-Aldrich, CR) was injected i.p. to assess the DNA synthesis of cells (particularly tumorous). In addition to the total body weight, tumours, livers, lungs, hearts, spleens and blood were also weighed. The organs were examined macroscopically, the tumours also histologically. Biochemical analysis of the plasma samples - assessment of the concentrations of total and conjugated bilirubin, as well as the activities of ALT (alanine aminotransferase) and AST (aspartate aminotransferase) - were performed on Modular PP (Roche Diagnostics, Mannheim, Germany) according to the manufacturer's instructions.

The care and handling of mice conformed to European Union recommendations on handling experimental animals and was approved by the Animal Ethics Commission of the Medical Faculty in Hradec Králové, CR (Nr. 30790/2010-30).

Histological evaluation. One hour before the animals were sacrificed, BrdU (Sigma-Aldrich, CR) was injected intraperitoneally (100 mg/ $\mathrm{kg}$ of body weight) to assess the DNA synthesis of cells. Samples of prepared tumours were fixed by immersion in $4 \%$ neutral formaldehyde for 3 days. Paraffin sections ( $7 \mu \mathrm{m}$ thick) were prepared by conventional histological processing. The indirect peroxidase-anti-peroxidase method was used for immunohistochemical analysis. The hydrolysis of DNA with $2 \mathrm{~N} \mathrm{HCl}$ was necessary prior to the incubation of 
slices with mouse monoclonal anti-BrdU (Dako, CR; dilution 1:100). Biotinylated anti-mouse secondary antibody (Jackson ImmunoResearch Lab., USA; dilution 1:500) and streptavidin conjugate of peroxidase (Dako, CR; dilution 1:300) were subsequently used. Visualization was performed conventionally by DAB (Sigma-Aldrich, $\mathrm{CR}$ ), and Gill's haematoxylin was used for counterstaining. Photomicrographs were made using an Olympus BX 51 microscope equipped with a DP 70 digital camera (Olympus, Prague, CR) and Quick Photo Camera 2.3 software (Promicra, Prague, CR).

Ex vivo DNA and protein synthesis assay. The above mentioned Ehrlich tumour was homogenized and inoculated i.p. ( $10^{6}$ tumour cells to female NMRI mice (see above)). The cells for this experiment were obtained from the peritoneal cavity on day 7 after i.p. inoculation. Cell suspensions were packed by low-speed centrifugation ( $600 \mathrm{x} \mathrm{g}$ for $10 \mathrm{~min}$ at $4{ }^{\circ} \mathrm{C}$ ). The cells were resuspended in Krebs III phosphate buffer (all components obtained from Sigma-Aldrich Co.), $\mathrm{pH} 7.4$, without calcium but enriched with D-glucose $(540 \mathrm{mg} / \mathrm{L})$ and ascitic plasma $(2.5 \%, \mathrm{v} / \mathrm{v})$. The cell suspensions were incubated for 150 min at $37{ }^{\circ} \mathrm{C}$ with the addition of $\left[6-{ }^{3} \mathrm{H}\right]$-thymidine $(73$ $\mathrm{kBq} / \mathrm{mL}$ of incubated suspension) and L-[U- $\left.{ }^{14} \mathrm{C}\right]$-amino acid mixture ( $5 \mathrm{kBq} / \mathrm{mL}$ of incubated suspension) obtained from Lacomed s.r.o., CR, and TOM (1 - $9 \mu \mathrm{M})$ or DOX (4.05 - 258.6 $\mu \mathrm{M})$. The cell density was $1.5 \times 10^{6}$ cells $/ \mathrm{mL}$ incubated suspension. Samples were taken at 30 min intervals from 0 to $150 \mathrm{~min}$ and processed by the method described by Mattern using filter paper discs ${ }^{21}$. The activities of 5\% trichloracetic acid-insoluble fractions were measured by liquid scintillation spectrometry (Triton scintillation fluid (Chemopetrol, CR), Tri-Carb 2900 TR liquid scintillation counter (PerkinElmer, Inc., U.S.A.). The $\mathrm{IC}_{50}$ was calculated as the concentration at which the initial velocity of precursor incorporation was halved compared to the controls. The mathematical model used is described in our previous paper ${ }^{22}$.

Western blot. Whole cell homogenate was prepared from cancer tissue in ice-cold RIPA buffer (Sigma) supplemented by protease inhibitors using an Ultra-turrax T10 Basic Disperser (IKA-Werke GmbH \& Co.KG, Germany) operating at $14500 \mathrm{rpm}$ ( 3 cycles for $10 \mathrm{~s}$ ). Supernatant containing proteins was obtained after a $3000 \mathrm{~g}$ centrifugation at $4{ }^{\circ} \mathrm{C}$ for $10 \mathrm{~min}$. The protein concentration was determined with BCA Protein Assay Kit (Pierce) and samples were stored at $-80{ }^{\circ} \mathrm{C}$. Proteins $(50 \mu \mathrm{g})$ were separated by SDS-PAGE, transferred to a PVDF membrane (Millipore), washed, and incubated with anti-PCNA (proliferating cell nuclear antigen) (Sigma-Aldrich, AV03018), anti-CD3 (Sigma-Aldrich, SAB4503580), anti-iNOS (Cayman Chem., Cat. 160862) and anti-pERK1/2 (Cell Signaling Technology, Cat. 4377) antibodies at dilutions of $1: 800,1: 500,1: 1000$, and 1:1000, respectively. Protein bands were visualized by means of horseradish peroxidaseconjugated secondary antibodies (GE Healthcare) and enhanced chemiluminescence reagents (Thermo Pierce).
Densitometry was performed using ScanMaker i900 (UMAX) and QuantityOne imaging software (BioRad). Equal protein loading was confirmed by the immunodetection of beta-actin.

Statistical Analysis. Data are presented as means and standard deviations. Two-Way Analysis of Variance with post-hoc multiple comparisons by Fisher's LSD test was used to test for differences. Survival times in groups are expressed as geometric mean with a $95 \%$ confidence interval. Kaplan-Meier curves and logrank tests were used to compare survival times in groups. The level of significance was $\alpha=0.05$. MS Excel 2003 and NCSS software was used for the calculations and statistical evaluations.

\section{RESULTS}

\section{Effect on the survival of tumour-bearing mice}

The mean overall survival of tumour bearing mice without therapy was 14.5 days. The dose of TOM with the greatest effect on the survival rate was $1 \mathrm{mg} / \mathrm{kg}$, both in the monotherapy and in combination with DOX (Fig. 2). However, only the combination of $1 \mathrm{mg} / \mathrm{kg}$ of TOM with DOX prolonged the survival time significantly compared with untreated tumour-bearing control mice $(P<0.01)$ and with doxorubicin monotherapy $(P<0.05)$. On the other hand, doxorubicin alone had no significant effect on the survival time.

\section{Effect on tumour growth}

Fig. 3 shows the weight of tumours in mice treated with saline, TOM, DOX or the TOM/DOX combination measured on day 8 and significantly documents differ-

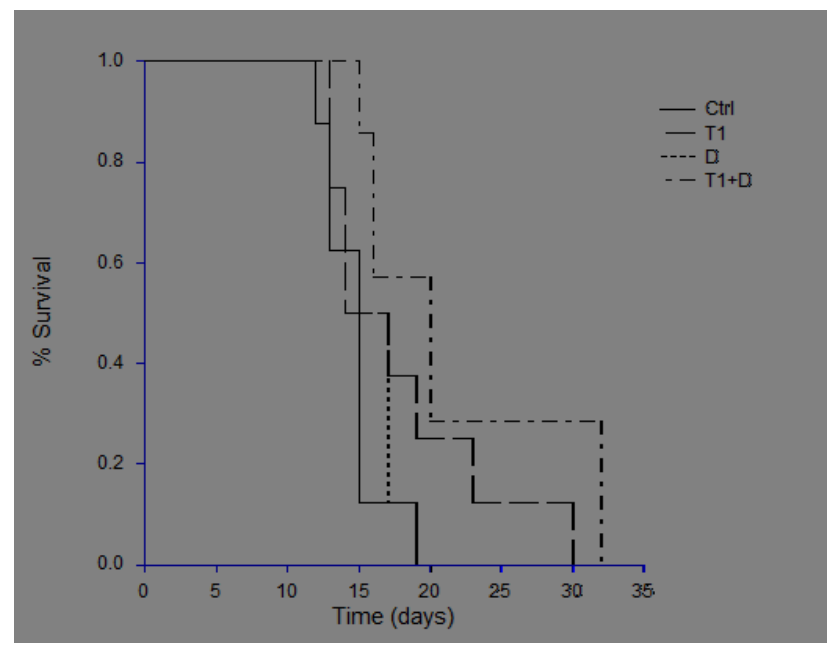

Fig. 2. Kaplan-Meier analysis of survival. The administration of $\alpha$-tomatine $1 \mathrm{mg} / \mathrm{kg}$ i.p. (T1) with doxorubicin $2 \mathrm{mg} / \mathrm{kg}$ i.v. (D) significantly prolonged the survival of tumour-bearing mice when compared with tumour-bearing controls treated with saline i.p. (Ctrl). The monotherapy with $\alpha$-tomatine $1 \mathrm{mg} / \mathrm{kg}$ i.p. had the second largest effect, though this was not statistically significant. This plot shows only some selected groups. 

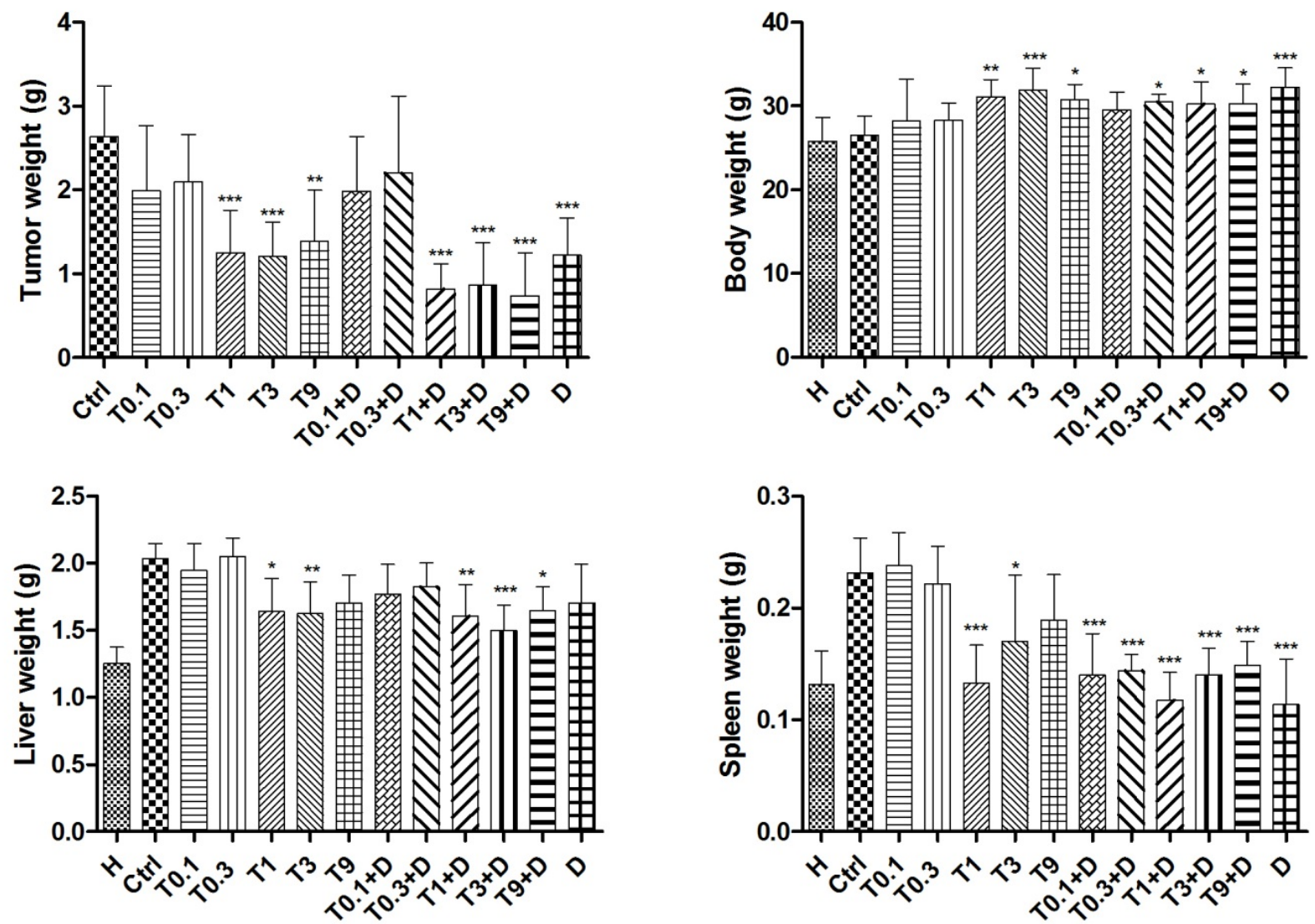

Fig. 3. Body weight and the weight of the solid Ehrlich tumour, liver and spleen (in grams) on day 8 of mice injected on days 1 , 4 and 7 i.p. with $\alpha$-tomatine and/or i.v. with DOX. Values are the means \pm SEM ( $n=8$ in each group). $\mathrm{Hg}-$ tumour-free control treated with saline; $\mathrm{Ctrl}$ - tumour-bearing control treated with saline; T0.1 - $\alpha$-tomatine $0.1 \mathrm{mg} / \mathrm{kg}$ i.p.; T0.3 - $\alpha$-tomatine $0.3 \mathrm{mg} /$ kg i.p.; T1 - $\alpha$-tomatine $1 \mathrm{mg} / \mathrm{kg}$ i.p.; T3 - $\alpha$-tomatine $3 \mathrm{mg} / \mathrm{kg}$ i.p.; T9 - $\alpha$-tomatine $9 \mathrm{mg} / \mathrm{kg}$ i.p.; $\mathrm{D}$ - doxorubicin $2 \mathrm{mg} / \mathrm{kg}$ i.v. Significantly different from the controls ( $\left.{ }^{*} P<0.05,{ }^{* *} P<0.01,{ }^{* * *} P<0.001\right)$.

ences in the effect of the used drugs. Both TOM and DOX alone as well as their combination had a significant inhibitory effect on tumour growth. The greatest effect was noted after the administration of TOM in doses of 1 , 3 and $9 \mathrm{mg} / \mathrm{kg}$ in combination with DOX. Fisher's LSD test revealed that the tumour weights in groups treated with TOM alone $(0.1-3 \mathrm{mg} / \mathrm{kg})$ did not differ significantly from those treated with its combination with DOX $(P>0.05)$. The groups subjected to ex vivo proteomic assays as well as to histological assessment were therefore chosen with respect to the optimal effect on survival and tumour growth.

\section{Effect on mitotic activity in vivo}

The microscopic structure of the tumours stained for mitotic activity (incorporation of BrdU) is depicted in Fig. 4. A slightly decreased density of newly generated (BrdUpositive) tumour cells was noted compared with untreated control mice (Fig. 4a) and groups treated with either the combination of $1 \mathrm{mg} / \mathrm{kg}$ of TOM and DOX (Fig. 4c) or $1 \mathrm{mg} / \mathrm{kg}$ of TOM alone (Fig. 4d). In group treated only with DOX (Fig. 4b), the decrease in mitotic activity was less apparent. However, in all evaluated tumours, clusters of intensely proliferating cells were separated by strips or fields of currently quiescent (non-dividing) cells. In mice which underwent any of the treatment methods, these areas of BrdU-negative cells increased (frequently markedly) in size (Figs. 4b-d). Precise quantitative analysis was, however, not possible due to the clonal origin of tumour cells resulting in the formation of typical clusters with a very irregular distribution of proliferating (BrdU-positive) cells (Figs. 4 a-d). Thus, the decrease in proliferating fraction was measured by quantification of PCNA using Western blot, which was verified in groups treated by TOM at 1 $\mathrm{mg} / \mathrm{kg}$ either alone or with doxorubicin (Fig. 5).

\section{Western blot}

To assess the major pathways that may be involved in anticancer process, we evaluated the presence of the CD3 antigen - the indicator of T-lymphocytes; phosphorylated ERK2 - a key active regulatory molecule; and iNOS (inducible nitric oxide synthase) - a target downstream of NF-kB as an indicator of its activation. We did not detect any significant changes in the expression of these proteins after TOM monotherapy (Fig. 6). The induction of iNOS was only observed in mice treated with both agents. 

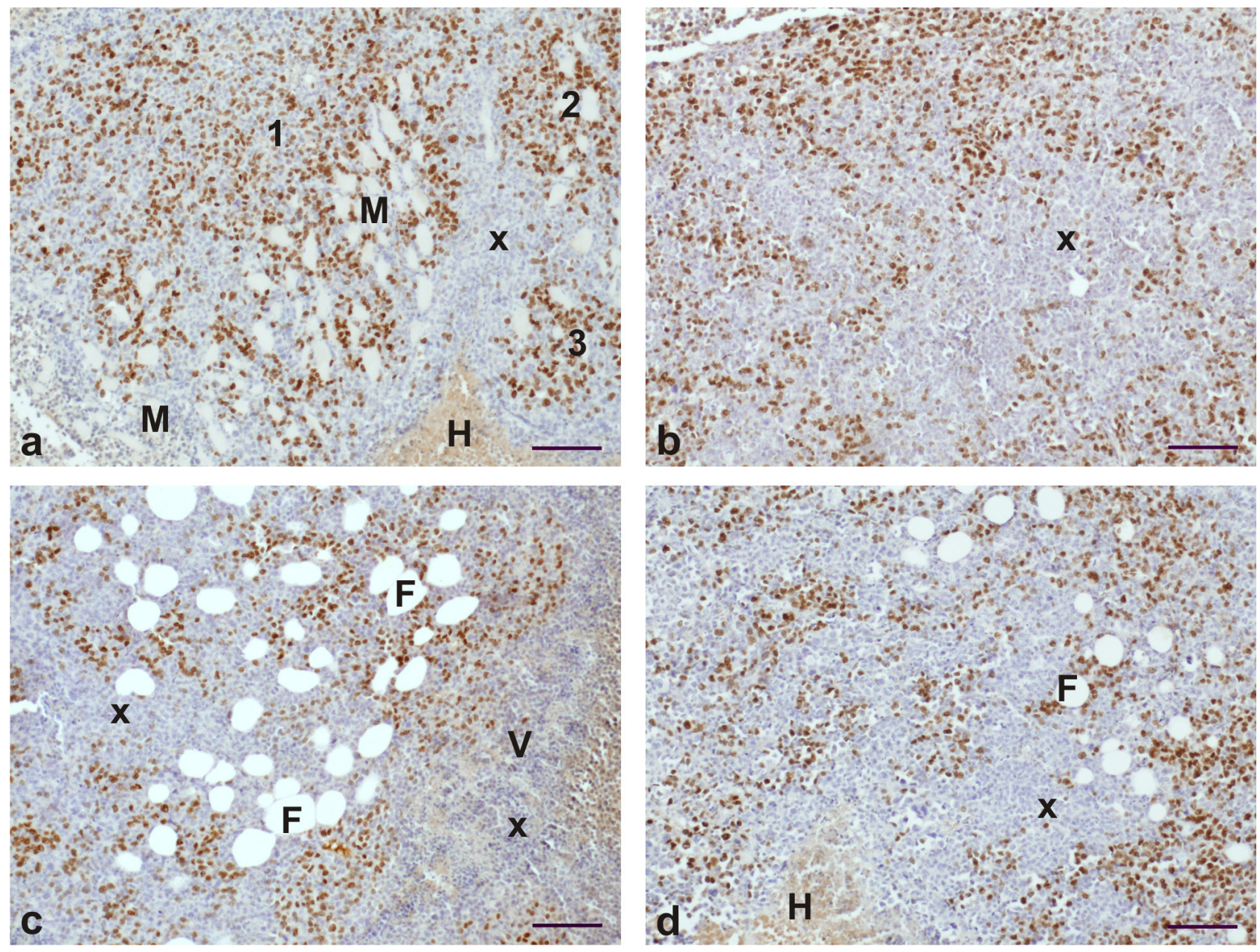

Fig. 4. Mitotic activity was demonstrated in areas of approximately similar location - next to the outer surface of the tumour taken from the solid nodous part. Clusters of intensely proliferating cells were separated by strips or fields (x) of currently quiescent (BrdU-negative) cells, which subsequently increased (frequently markedly) in size in all treated groups. Some parts of the tumour (in all groups) were richly vascularized $(\mathrm{V})$ but also haemorrhagic $(\mathrm{H})$ and necrotic areas of different size were frequently present. The host tissue (skeletal muscles - M, fat cells - F or connective tissue) was incorporated into the tumour by its infiltrative and invasive growth.

a - Untreated tumour-bearing control: The density of proliferating BrdU-positive tumour cells was higher when compared with the treated groups; the typical clustered appearance (e.g. 1, 2, 3) confirms the clonal origin of non-differentiated tumorous cells. $\mathrm{b}$ - Treated with doxorubicin $(2 \mathrm{mg} / \mathrm{kg})$ : The number of BrdUpositive tumour cells decreased only slightly but the areas of "quiescent" cells were noticeably larger compared with group (a). c - Treated with $\alpha$-tomatine ( $1 \mathrm{mg} / \mathrm{kg}$ ) and doxorubicin ( $2 \mathrm{mg} / \mathrm{kg}$ ): A decrease in the density of BrdU-positive tumour cells was noted in many parts of the tumour compared with group (b) and especially with group (a). d - Treated with $\alpha^{-}$ tomatine $(1 \mathrm{mg} / \mathrm{kg})$ : No significant difference in mitotic activity was found in comparison with group (c).

Anti-BrdU, Gill's haematoxylin. Bar $100 \mu \mathrm{m}$.

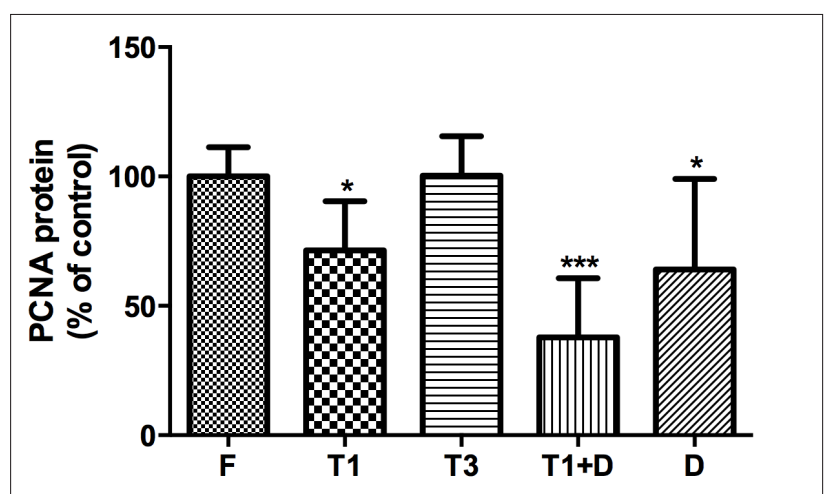

Fig. 5. The presence of PCNA in tumour homogenates from mice treated with saline (F); $\alpha$-tomatine $1 \mathrm{mg} / \mathrm{kg}$ i.p. (T1); $\alpha$-tomatine $3 \mathrm{mg} / \mathrm{kg}$ i.p. (T3); and the combination of $\alpha$-tomatine $1 \mathrm{mg} / \mathrm{kg}$ i.p. with doxorubicin $2 \mathrm{mg} / \mathrm{kg}$ i.v. (T1 + $\mathrm{D})$. In the group receiving $\mathrm{T} 1$ and $\mathrm{D}$, the greatest inhibition of DNA synthesis was observed. Values are the means \pm SEM. Significantly different from the controls $\left({ }^{*} P<0.05,{ }^{* *} P<\right.$ $0.001)$. 


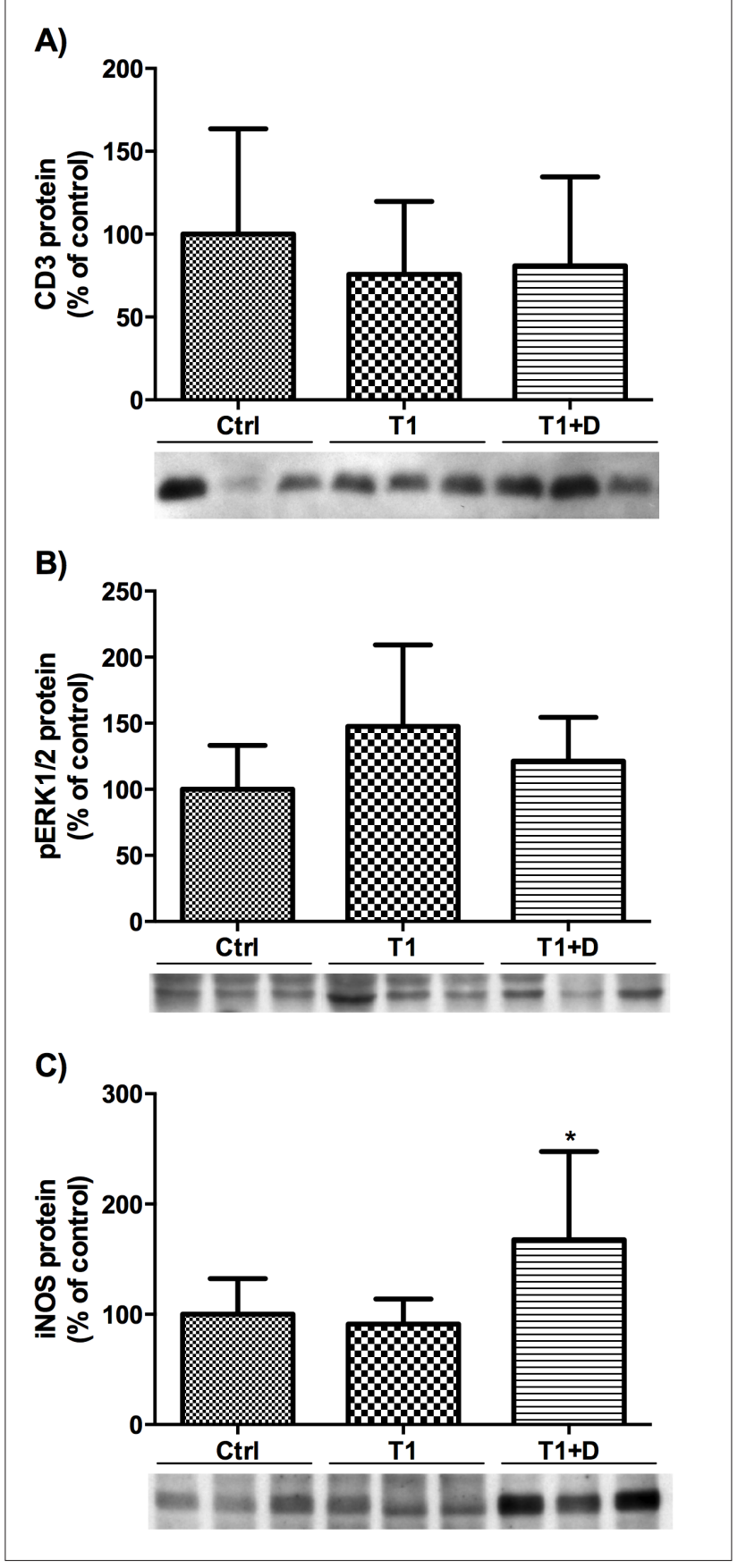

Fig. 6. The presence of CD3 antigen - the indicator of T-lymphocytes, phosphorylated ERK2 and iNOS in tumour homogenates from mice treated with saline $(\mathrm{Ctrl}), \alpha$-tomatine 1 $\mathrm{mg} / \mathrm{kg}$ i.p. (T1) and the combination of $\alpha$-tomatine $1 \mathrm{mg} / \mathrm{kg}$ i.p. with doxorubicin $2 \mathrm{mg} / \mathrm{kg}$ i.v. (T1 + D). No significant changes in expression of these proteins after $\alpha$-tomatine monotherapy were detected. The induction of iNOS was only observed in mice treated with both agents. Values are the means \pm SEM. Significantly different from the controls $\left({ }^{*} P<0.05\right)$.

\section{Pathology and biochemical analysis of the plasma}

No macroscopic metastases were found in the organs. The body weights of mice treated with TOM $1-9 \mathrm{mg} / \mathrm{kg}$ or DOX, either alone or in combination with TOM $0.3-9$ $\mathrm{mg} / \mathrm{kg}$, were significantly higher than those of untreated mice, both the tumour-free and the tumour-bearing controls (Fig. 3). Hepatomegaly, which was distinct in the
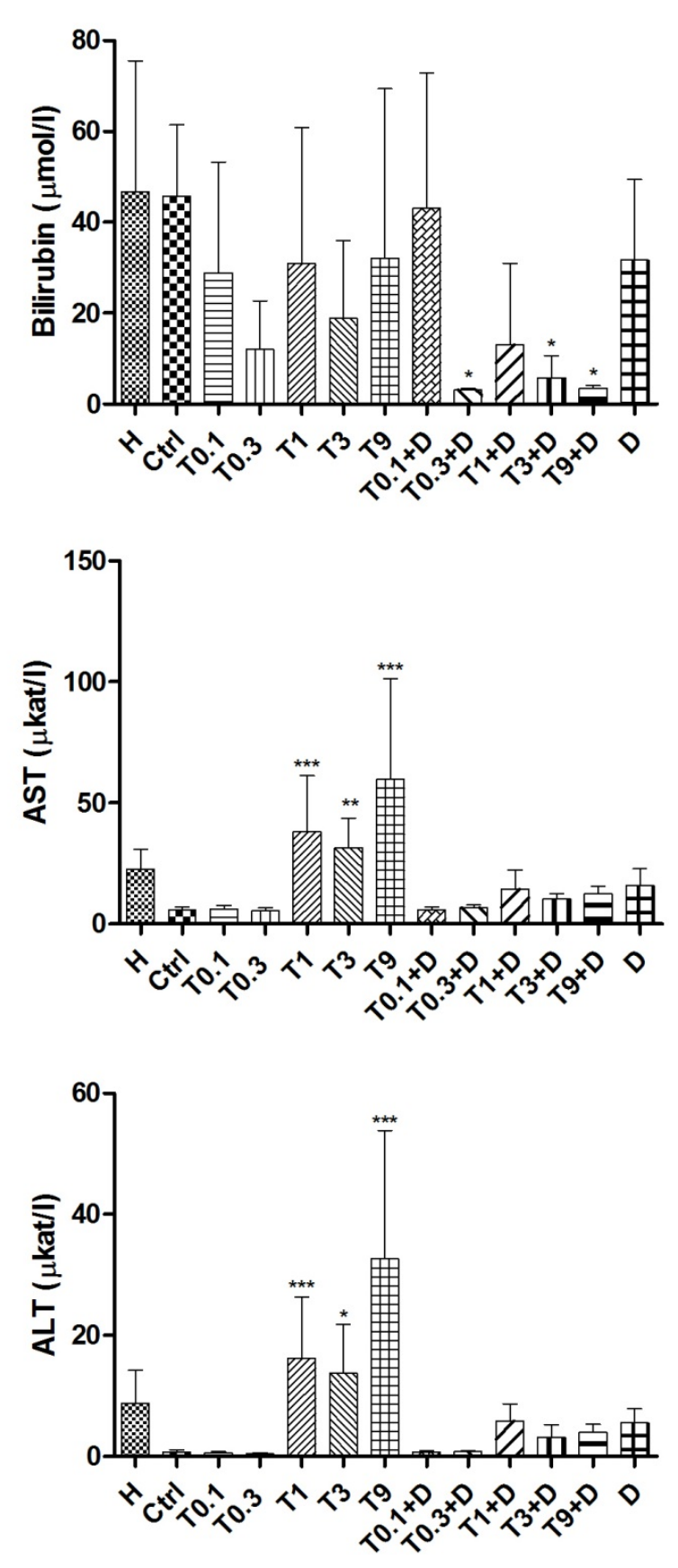

Fig. 7. The concentration of total bilirubin and the activities of AST and ALT in serum on day 8 of mice injected on days 1, 4 and 7 i.p. with $\alpha$-tomatine and/or i.v. with DOX. Values are the means \pm SEM ( $n=8$ in each group). $\mathrm{H}$ - tumour-free control treated with saline; $\mathrm{Ctrl}$ - tumour-bearing control treated with saline; T1 - $\alpha$-tomatine $1 \mathrm{mg} / \mathrm{kg}$ i.p.; T3 - $\alpha$-tomatine $3 \mathrm{mg} / \mathrm{kg}$ i.p.; T9 - $\alpha$-tomatine $9 \mathrm{mg} / \mathrm{kg}$ i.p.; D - doxorubicin $2 \mathrm{mg} / \mathrm{kg}$ i.v. Significantly different from the controls $\left({ }^{*} P<0.05,{ }^{* *} P<0.01\right.$, $\left.{ }^{* * *} P<0.001\right)$.

tumour-bearing mice, was reduced in groups receiving 1 and $3 \mathrm{mg} / \mathrm{kg}$ of TOM as well as in the combination groups with TOM $1-9 \mathrm{mg} / \mathrm{kg}$ (but not in the group treated only with DOX) when compared to the tumour-bearing controls (Fig. 3). Similar results were obtained in relation to the weight of the spleen, where - in addition to the groups treated with only 1 and $3 \mathrm{mg} / \mathrm{kg}$ of TOM - all 
groups receiving DOX, including all TOM/DOX combination groups, displayed reduced or no splenomegaly (Fig. 3). Interestingly, the activities of ALT and AST in blood serum were increased only in mice treated with the monotherapy of TOM $1-9 \mathrm{mg} / \mathrm{kg}$. On the other hand, in groups receiving combinations of TOM and DOX, lower concentrations of total bilirubin were observed (Fig. 7). The levels of conjugated bilirubin did not differ between the groups (data not shown).

\section{Effect on DNA and protein synthesis ex vivo}

TOM inhibited the incorporation of the $\left[6-{ }^{3} \mathrm{H}\right]$ thymidine and L-[U- $\left.{ }^{14} \mathrm{C}\right]$-amino acid mixture $\left(\mathrm{IC}_{50}\right.$ values were 8.7 and $6.6 \mu \mathrm{M}$, respectively), which can be interpreted as the inhibition of both DNA and protein synthesis; however, the effect on protein synthesis appears to be even stronger. DOX inhibited only DNA synthesis $\left(\mathrm{IC}_{50}=7.7 \mu \mathrm{M}\right)$; its effect on protein synthesis could not be detected.

\section{DISCUSSION}

In the present study, we show for the first time the effect of i.p. injected TOM against a solid tumour in vivo. We also show the beneficial effect of the concurrent intravenous administration of DOX. TOM reduced the growth of the solid Ehrlich tumour, which resulted in a prolongation of the survival of tumour-bearing animals receiving a combination therapy of TOM and DOX. Our results suggest that the optimal dose of TOM is close to $1 \mathrm{mg} /$ $\mathrm{kg}$. Lower doses were not effective, as they were incapable of reducing tumour growth. Higher doses, on the other hand, did not offer any additional activity. These findings are unique, because with the exception of one very recent study on leukaemia xenograft in mouse models ${ }^{16}$, no similar data have been reported yet for the effects of TOM or related glycoalkaloids from the Solanaceae family, in comparable tumour-bearing mammal models.

The use of the Ehrlich tumour, a poorly differentiated malignant tumour derived from a spontaneous adenocarcinoma of the mouse mammary gland in immunocompetent mice, has the advantage of involving the immune system in the inhibition of tumour progression ${ }^{23-25}$. In order to avoid excessive curability arising from the host's immune response ${ }^{26}$, we started the treatment one day after the inoculation of tumour cells. Moreover, we attempted to detect the CD3 surface antigen of T-cells, as the hallmark of the activation of immune anti-cancer defence in this animal model ${ }^{27}$, and saw no influence of either TOM $(1 \mathrm{mg} / \mathrm{kg}$ ) or DOX on tumour infiltration by CD3+ cells. This suggests that the mechanisms of activated innate immunity may not be crucial for the observed in vivo anticancer effect of TOM. The recent findings in immunodeficient mice ${ }^{16}$ support this conclusion.

In line with previous reports ${ }^{7,8}$, in our study TOM was also able to inhibit the growth of cancer cells ex vivo. In this case, TOM blocked both DNA and protein synthesis, whereas doxorubicin exerted only a weak inhibitory action against protein synthesis, which is in accordance with previous findings ${ }^{28,29}$. The stronger effect of TOM on protein than on DNA synthesis might indicate an effect on energy metabolism ${ }^{30}$ rather than the primary induction of DNA damage or inhibition of replicative DNA synthesis. In order to investigate the global effect of TOM on cell functions, we analysed the expression of proteins described formerly as potential targets for TOM action in ex vivo samples of tumours: iNOS as a NF- $\mathrm{BB}$ downstream target, and phosphorylated ERK2. The negative findings in this area contradict previous in vitro studies and suggest another mechanism, which is probably different from that of doxorubicin, because TOM did not interfere with anthracycline and potentiated its anticancer activity. This synergism may also be the result of P-gp (permeability glycoprotein) efflux transporter blockade, which was detected previously for tomatidine, the aglycon of $\mathrm{TOM}^{31}$. The impact on cell membrane structures would be even more important for the overall action of TOM because it interacts strongly with cholesterol and may cause cell membrane disruption and intracellular stress ${ }^{32-34}$. Whether TOM can also induce apoptosis in solid tumours such as mammary adenocarcinoma in the manner described by Chao et al. ${ }^{16}$ will need to be clarified by further investigation. Overall, the mechanism of TOM anticancer activity appears to be complex, not well understood and may serve as a very interesting focus for further research.

Splenomegaly, caused by the accumulation of lymphocytic elements, is typically associated with progression of the Ehrlich tumour, along with thymus atrophy ${ }^{35-38}$. The weight of the tumour-free liver was also found to correspond with the growth of subcutaneous murine adenocarcinoma $^{39}$. Since this effect on both organs was attenuated in the presence of agents in concentrations which also effectively reduced cancer growth, we speculate that it may be attributable to the anticancer activity of both drugs rather than to their direct effect in the organs. Although we did not evaluate whether TOM at the doses used had an effect on liver weight in healthy mice, Friedman et $\mathrm{al}^{40}$ demonstrated no significant effect of feeding healthy mice TOM ( $2.4 \mathrm{mmol} / \mathrm{kg}$ for $7 \mathrm{~d}$ ) on liver or body weight, in contrast to the related potato glycoalkaloids. In that study, however, the different bioavailability after oral administration may play a role. We detected an increase in the activities of ALT and AST in TOM i.p. treated groups. Similar results have also been reported by Dalvi ${ }^{41}$ after i.p. injection of a close congener of TOM, $\alpha$-solanine (20 $\mathrm{mg} / \mathrm{kg}$ ) to rats. Thus, TOM seems to be hepatotoxic too, because several previous studies on a similar cancer model reported a decrease in ALS/AST levels back to the levels of tumour free mice after treatment with liver-friendly anticancer agents ${ }^{42,43}$. However, the lack of an increase in ALT/AST upon injection with the same doses of TOM 30 min after DOX had been administered - as observed in our study - requires further investigation. One possible explanation may be that DOX interferes with the binding of TOM to the cytoplasmatic membrane of hepatocytes.

The overall toxicity of TOM depends on the route of administration. Whereas oral TOM shows apparently 
lower toxicity than the potato glycoalkaloids $\alpha$-chaconine and $\alpha$-solanine ${ }^{1,40}$, presumably due to the poor absorption of TOM complexes with cholesterol in the gut, the lethal i.p. doses of TOM and potato glycoalkaloids are similar. In mice, the parenteral toxicity of TOM is characterized by an $\mathrm{LD}_{50}$ of $32.4 \mathrm{mg} / \mathrm{kg}$ for i.p. administration $^{17}$ and of $18 \mathrm{mg} / \mathrm{kg}$ for intravenous injection ${ }^{44}$. We observed peripheral necrosis (tail tips, auricles) at doses as high as $5 \mathrm{mg} / \mathrm{kg}$ (i.v.) and $30 \mathrm{mg} / \mathrm{kg}$ (i.p.) (data not shown). Such a narrow therapeutic window for the intravenous treatment was one of the reasons we chose the intraperitoneal route of administration at the selected dose spectrum. Death after administration of a lethal dose of TOM, if it occurs, is sudden. The symptoms following parenteral injection include short-lived hypotension without a great effect on heart rate, an increased respiratory rate, and haemolysis ${ }^{44}$. Although haemolysis is reported, we demonstrated reduced concentrations of total bilirubin in serum, especially in groups where TOM was combined with DOX. The levels of conjugated bilirubin in serum were unaffected either by the tumour, or by TOM alone. One of the possible underlying mechanisms of the total hypobilirubinaemia observed might be the interaction of the compounds with the binding of unconjugated bilirubin to plasma protein and the potentiation of its elimination by the liver. Another possible mechanism might be the induction of UDP-glucuronyltransferase, as DOX was reported to be its strong inducer ${ }^{45}$. In conclusion, our results suggest that TOM, especially in combination with doxorubicin, may be a promising agent for the treatment of malignant solid tumours. Despite growing knowledge of the mechanisms of TOM action in cancer cells, most aspects still remain unclear. Parallel organ toxicity, especially potential liver effects of the agent, requires careful attention when performing in vivo studies in the future.

\section{ACKNOWLEDGEMENTS}

This study was supported by the grant GACR P303/12/P536 and the programme PRVOUK P37/01 of the Charles University in Prague. The authors would like to acknowledge the skilful technical assistance of Mrs. Lenka Kriesfalusyova, Mrs. Hana Lastuvkova, Mrs. Jitka Hajkova, Mrs. Petra Kazimirova and Mrs. Milada Hetesova. Grateful acknowledgement for proofreading goes to Mr. Matthew Nicholls.

\section{CONFLICT OF INTEREST STATEMENT}

Author's conflict of interest disclosure: None declared.

\section{REFERENCES}

1. Friedman M. Tomato glycoalkaloids: Role in the plant and in the diet. J Agric Food Chem 2002;50:5751-80.

2. Schmidt B, Ribnicky DM, Poulev A, Logendra S, Cefalu WT, Raskin I. A natural history of botanical therapeutics. Metabolism 2008;57:S3-9.
3. Friedman M, Fitch TE, Yokoyama WE. Lowering of plasma LDL cholesterol in hamsters by the tomato glycoalkaloid tomatine. Food Chem Toxicol 2000;38:549-53.

4. Thorne HV, Clarke GF, Skuce R. The inactivation of herpes simplex virus by some Solanaceae glycoalkaloids Antiviral Res 1985;5:335-43.

5. Morrow WJW, Yang YW, Sheikh NA. Immunobiology of the tomatine adjuvant. Vaccine 2004;22:2380-4.

6. Friedman M, McQuistan T, Hendricks JD, Pereira C, Bailey GS Protective effect of dietary tomatine against dibenzo[a,l]pyrene (DBP)-induced liver and stomach tumors in rainbow trout. Mol Nutr Food Res 2007;51:1485-91.

7. Lee KR, Kozukue N, Han JS, Park JH, Chang EY, Baek EJ, Chang JS Friedman M. Glycoalkaloids and metabolites inhibit the growth of human colon (HT29) and liver (HepG2) cancer cells. J Agric Food Chem 2004; 19:2832-9.

8. Friedman M, Levin CE. Tomatine-containing green tomato extracts inhibit growth of human breast, colon, liver, and stomach cancer cells. J Agric Food Chem 2009;57:5727-33.

9. Chiu FL, Lin JK. Tomatidine inhibits iNOS and COX-2 through suppression of NF-kappaB and JNK pathways in LPS-stimulated mouse macrophages. FEBS Lett 2008;582:2407-12.

10. Shih YW, Shieh J M, Wu PF, Lee YC, Chen YZ, Chiang TA. a-Tomatine inactivates $\mathrm{PI} 3 \mathrm{~K} / \mathrm{Akt}$ and ERK signaling pathways in human lung adenocarcinoma $\mathrm{A} 549$ cells: effect on metastasis. Food Chem Toxicol 2009;47:1985-95.

11. Liao DW, Wang L, Zhang XG, Liu MQ. Expression and significance of PTEN/PI3K signal transduction-related proteins in non-small cell lung cancer Chin J Canc 2006; 25:1238-42.

12. Itoh $Y$, Nagase $H$. Matrix metalloproteinases in cancer. Essays Biochem 2002;38,21-36.

13. Duffy MJ, Duggan C. The urokinase plasminogen activator system: A rich source of tumor markers for the individualised management of patients with cancer. Clin Biochem 2004;37:541-8.

14. Lee ST, Wong PF, Cheah SC, Mustafa MR Alpha-tomatine induces apoptosis and inhibits nuclear factor-kappa B activation on human prostatic adenocarcinoma PC-3 cells. PLoS ONE 2011;6:e18915.

15. Shieh JM, Cheng TH, Shi MD, Wu PF, Chen Y, Ko SC, Shih YW. a-Tomatine suppresses invasion and migration of human non-small cell lung cancer $\mathrm{NCl}-\mathrm{H} 460$ cells through inactivating FAK/PI3K/Akt signaling pathway and reducing binding activity of NF-KB. Cell Biochem Biophys 2011;60:297-310.

16. Chao MW, Chen CH, Chang YL, Teng CM, Pan SL. a-TomatineMediated Anti-Cancer Activity In Vitro and In Vivo through Cell Cycleand Caspase-Independent Pathways. PLoS ONE 2012;9:e44093.

17. Kúdelová J, Seifrtová $M$, Suchá $L$, Tomšík $P$, Havelek $R$, Rezáčová $M$ Alpha-tomatine activates cell cycle checkpoints in the absence of DNA damage in human leukemic MOLT-4 cells. J Appl Biomed 2013;11:93-103.

18. Nishie K, Norred WP, Swain AP. Pharmacology and toxicology of chaconine and tomatine. Res Commun Chem Pathol Pharmacol 1975; 12:657-68.

19. Awara WM, El-Sisi AE, El-Sayad ME, Goda AE. The potential role of cyclooxygenase-2 inhibitors in the treatment of experimentally-induced mammary tumour: does celecoxib enhance the anti-tumour activity of DOX? Pharmacol Res 2004;50:487-98.

20. Klein HO, Toermer HJ, Christian E, Coerper C, Lennartz KJ, Akokan G. Experimental investigations on a sequential combination chemotherapy protocol. J Cancer Res Clin Oncol 1980;96:65-78.

21. Mattern J, Kaufmann M, Wayss K, Volm M. Studies on the Drug Sensitivity of Short Term Cultivated Tumor Cell Suspensions. In: Dendy, PP,editor. Human Tumors in Short Term Culture, Academic Press, London (UK), New York (NY), San Francisco (CA); 1976. p 301.

22. Tomšík P, Stoklasová A, Mičuda S, Niang M, Šuba P, Knížek J, Řezáčová M. Evaluation of the antineoplastic activity of L-rhamnose in vitro. A comparison with 2-deoxyglucose. Acta Med (Hradec Králové) 2008;51:113-9.

23. Pessina A, Brambilla P, Mocarelli P. Surface antigen on Ehrlich ascites tumor cells. Biomedicine 1980;33:105-9.

24. Segura JA, Barbero LG, Márquez J. Early tumor effect on splenic Th lymphocytes in mice. FEBS Lett 1997;414:1-6.

25. Céspedes MV, Casanova I, Parreño M, Mangues R. Mouse models in oncogenesis and cancer therapy. Clin Transl Oncol 2006;8:318-29.

26. Polin L, Corbett TH, Roberts BJ, Lawson AJ, Leopold III WR, White K, Kushner J, Hazeldine S, Moore R, Rake J, Horwitz JP. Transplantable 
Syngeneic Rodent Tumors. In: Teicher BA, editor. Tumor Models in Cancer Research, $2^{\text {nd }}$ edn. Humana Press, Springer: New York (NY), Dordrecht (Netherlands), Heidelberg (Germany), London (UK); 2011. p 47

27. Haque E, Baral R. Neem (Azadirachta indica) leaf preparation induces prophylactic growth inhibition of murine Ehrlich carcinoma in Swiss and C57BL/ 6 mice by activation of NK cells and NK-T cells. Immunobiology 2006;211:721-31.

28. Israel M, Idriss JM, Koseki Y, Khetarpal VK. Comparative effects of adriamycin and DNA-non-binding analogues on DNA, RNA, and protein synthesis in vitro. Cancer Chemother Pharmacol 1987;20:277-84.

29. Schaefer A, Boldt J, Westendorf J, Steinheider G, Marquardt H. Inhibition of amino acid uptake and incorporation into proteins in Friend erythroleukemia cells by the anthracycline antitumor antibiotic aclacinomycin A. Biochem Pharmacol 1988;37: 1377-82.

30. Ebbehoj E, Langkjer ST. Comparison between different parameters of cell viability. In vitro studies in a human cervix cancercell line. J Exp Clin Cancer Res 1995;14:95-101.

31. Lavie Y, Harel-Orbital T, Gaffield W, Liscovitch M. Inhibitory effect of steroidal alkaloids on drug transport and multidrug resistance in human cancer cells. Anticancer Res 2001;21:1189-94.

32. Keukens EA, de Vrije T; van den Boom C, de Waard P, Plasman $\mathrm{HH}_{\text {, }}$ Thiel F, Chupin V, Jongen WM, de Kruijff B. Molecular basis of glycoalkaloid induced membrane disruption. Biochim Biophys Acta 1995; 1240:216-28

33. Keukens EA, de Vrije $T$, Jansen LA, de Boer $H$, Janssen $M$, de Kroon Al, Jongen WM, de Kruijff B. Glycoalkaloids selectively permeabilize cholesterol containing biomembranes. Biochim Biophys Acta 1996;1279:243-50.

34. Walker BW, Manhanke N, Stine KJ. Comparison of the interaction of tomatine with mixed monolayers containing phospholipid, egg sphingomyelin, and sterols. Biochim Biophys Acta 2008;1778:224457.
35. Hartveit F. The growth of Ehrlich's ascites carcinoma in $\mathrm{C} 3 \mathrm{H}$ mice and in mice of an unrelated closed colony. Splenomegaly following intraperitoneal transplantation. Br J Cancer 1966;20:825-30.

36. Lala PK, Terrin M, Lind C, Kaizer L. Hemopoietic redistribution in tumor-bearing mice. Exp Hematol 1978;6:283-98.

37. Rivenson A, Schnelle V, Moroson H, Madden R, Herp A. Variable response of spleen to ehrlich's tumor according to the physical form (ascitic or solid) of the tumor. Experientia 1981;37:195-7.

38. Queiroz ML, Valadares MC, Bincoletto C, Dieamant GC. Ehrlich ascites tumor as a tool in the development of compounds with immunomodulatory properties. Immunopharmacol Immunotoxicol 2004;26:511-25.

39. Theologides A, Pegelow CH. Liver weight changes during distant growth of transplanted tumor. Proc Soc Exp Biol Med 1970;134:11048.

40. Friedman M, Henika PR, Mackey BE. Feeding of potato, tomato and eggplant alkaloids affects food consumption and body and liver weights in mice. J Nutr 1996;126:989-9.

41. Dalvi RR. Comparative assessment of the effect of solanine administered orally and intraperitoneally on hepatic dysfunction in male rats. Jpn J Vet Sci (Nihon Juigaku Zasshi) 1985;47:657-9.

42. Kathiriya A, Das K, Kumar EP, Mathai KB. Evaluation of antitumor and antioxidant activity of Oxalis Corniculata Linn. against ehrlich ascites carcinoma on mice. Iran J Cancer Prev 2010;3:157-65.

43. Naveena, Bharath BK, Selvasubramanian. Antitumor activity of Aloe vera against Ehrlich ascitis carcinoma (EAC) in Swiss albino mice. Int J Pharm Bio Sci 2011;2:400-9.

44. Wilson RW, Poley GH, de Eds F. Some pharmacologic and toxicologic properties of tomatine and its derivatives. Toxicol Appl Pharmacol 1961;3:39-48.

45. Mimnaugh EG, Trush MA, Ginsburg E. The effects of adriamycin in vitro and in vivo on hepatic microsomal drug-metabolizing enzymes: Role of microsomal lipid peroxidation. Toxicol Appl Pharmacol 1981;61:313-25. 